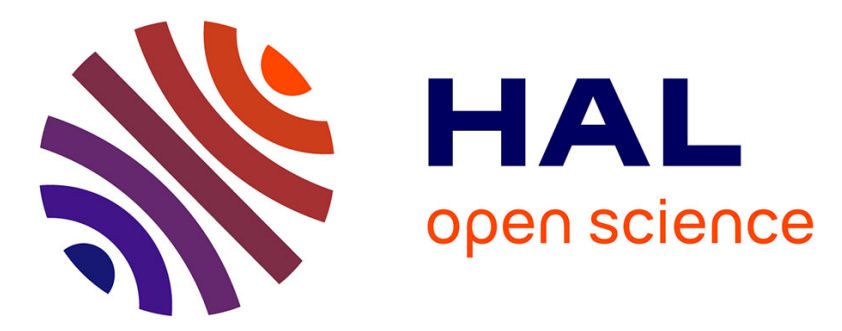

\title{
A human pathology-related mutation prevents import of an aminoacyl-tRNA synthetase into mitochondria
}

Marie Messmer, Catherine Florentz, Hagen Schwenzer, Gert C. Scheper, Marjo S. van Der Knaap, Laurence Maréchal-Drouard, Marie Sissler

\section{- To cite this version:}

Marie Messmer, Catherine Florentz, Hagen Schwenzer, Gert C. Scheper, Marjo S. van Der Knaap, et al.. A human pathology-related mutation prevents import of an aminoacyl-tRNA synthetase into mitochondria. Biochemical Journal, 2011, 433 (3), pp.441-446. 10.1042/BJ20101902 . hal-00558103

\section{HAL Id: hal-00558103 \\ https://hal.science/hal-00558103}

Submitted on 21 Jan 2011

HAL is a multi-disciplinary open access archive for the deposit and dissemination of scientific research documents, whether they are published or not. The documents may come from teaching and research institutions in France or abroad, or from public or private research centers.
L'archive ouverte pluridisciplinaire HAL, est destinée au dépôt et à la diffusion de documents scientifiques de niveau recherche, publiés ou non, émanant des établissements d'enseignement et de recherche français ou étrangers, des laboratoires publics ou privés. 


\title{
A human pathology-related mutation prevents import of an aminoacyl- tRNA synthetase into mitochondria
}

\author{
Marie Messmer ${ }^{\dagger}$, Catherine Florentz ${ }^{\dagger}$, Hagen Schwenzer ${ }^{\dagger}$, Gert C. Scheper ${ }^{*}$, Marjo S. van der \\ Knaap ${ }^{\ddagger}$, Laurence Maréchal-Drouard ${ }^{{ }^{*}}$ and Marie Sissler ${ }^{\dagger *}$
}

† Architecture et Réactivité de l'ARN, Université de Strasbourg, CNRS, IBMC, 15 rue René Descartes, F-67084 Strasbourg, France.

* Department of Pediatrics and Child Neurology, VU University Medical Center, 1081 HV Amsterdam, The Netherlands.

§ Institut de Biologie Moléculaire des Plantes, UPR 2357, CNRS, conventionné avec

l'Université de Strasbourg, 12 rue du Général Zimmer, F-67084 Strasbourg, France.

*, To whom correspondence should be addressed:

E-mail: m.sissler@ibmc-cnrs.unistra.fr. Phone: +33(0)3 88417057 - Fax: +33 (0)3 8841 602218

E-mail: laurence.drouard@ibmp-cnrs.unistra.fr. Phone: +33 (0)3 88417240 - Fax: +33 (0)3 88614442

Short title (page heading): Aminoacyl-tRNA synthetase import defect in mitochondrial disorder 


\section{SYNOPSIS}

Mutations in the nuclear gene coding for the mitochondrial aspartyl-tRNA synthetase, a key enzyme for mitochondrial translation, are correlated with leukoencephalopathy. Ser $_{45}$ to Gly $_{45}$ mutation is located in the predicted targeting signal of the protein. We demonstrate here, by in vivo and in vitro approaches, that this pathology-related mutation impairs the import process across mitochondrial membranes.

Keywords: Organelle / Pathology-related mutation / Aminoacyl-tRNA synthetase / Protein import / Translation machinery / Translocation 


\section{INTRODUCTION}

The mitochondrion has many fundamental functions in e.g. metabolic pathways, redox processes, energy production or apoptosis. The link between mitochondrial energetic dysfunction and cancer, aging phenomena and a broad range of metabolic and degenerative diseases is becoming more and more recognized [1]. Mitochondrial (mt) disorders can be caused by mutations in mt DNA genes encoding either a core protein of an oxidative phosphorylation complex or rRNAs and tRNAs required for mt translation. Additionally, mutations in nuclear genes encoding mt proteins are increasingly found to be associated with $\mathrm{mt}$ disorders, with the hypothesis that they would even be more common than mt DNA mutations [2].

An emerging field of neuromuscular and neurodegenerative disorders is linked to mutations in nuclear encoded factors of the mt translation machinery [3] and especially $\mathrm{mt}$ aminoacyl-tRNA synthetases (mt-aaRS). "Leukoencephalopathy with brain stem and spinal cord involvement and lactate elevation" (LBSL) is a monogenic disease associated with a large variety of mutations affecting the human nuclear gene DARS2, encoding the mt aspartyltRNA synthetase (mt-AspRS) [4] and novel mutations in this gene were reported since [5, 6]. Deleterious mutations in RARS2 (mt-ArgRS) are associated with pontocerebellar hypoplasia [7] and mutations in YARS2 (mt-TyrRS) with myopathy, lactic acidosis and sideroblastic anemia [8]. Missense mutations in GARS (encoding both cytosolic and mt-GlyRS) cause a variant of Charcot-Marie-Tooth disease $[9,10]$.

While mutations in RARS2 and YARS2 alter aminoacylation properties of mt-ArgRS and mt-TyrRS, consequences of the mutations affecting mt-AspRS are intriguingly different. Indeed, in vitro activities of the subset of tested mutants so far only revealed a limited loss of their aminoacylation properties. Additionally, when respiratory chain complex activities were examined in fibroblast and lymphoblasts, no apparent dysfunctions were observed. Tissuespecific parameters and/or consequences on alternative functions of the aaRS have to be considered $[4,5]$.

Here, we are interested in the molecular consequences of the p.Ser45Gly (S45G) change in mt-AspRS that was identified in LBSL patients. Ser ${ }_{45}$ resides within the predicted mitochondrial targeting sequence (MTS) of mt-AspRS [11] (Fig. 1). Most nuclear-encoded mt proteins possess a unique MTS, decisive for their presence in mitochondria. Mt proteins synthesized in the cytosol are first targeted to the surface of mitochondria via their interaction with chaperones. The MTSs are then specifically recognized by mt outer membrane receptors before guiding the precursor proteins through translocase complexes of the outer and inner membrane. Finally, MTSs are identified and cut off by $\mathrm{mt}$ processing peptidases, releasing mature proteins (reviewed in e.g. [12-16]). We have investigated the consequences of S45G mutation on targeting, binding, translocation and processing steps of mt-AspRS. We show that this pathogenic mutation strongly affects mt-AspRS translocation through the $\mathrm{mt}$ membranes. This is the first time an import defect of a mt translation machinery actor is associated with a severe human brain disorder.

\section{EXPERIMENTAL}

\section{Cloning}

Constructs used in the confocal microscopy experiments were cloned into pcDNA3.1/CTGFP-TOPO ${ }^{\circledR}$ vector (Invitrogen) following the manufactor's procedures. PCR fragments corresponding to MTS-GFP, MTS-mt-AspRS-GFP and MTS(S45G)-mt-AspRS-GFP were generated using the pEGFP-N1-DARS2 and pEGFP-N1-(S45G)-DARS2 plasmids. These plasmids contain the full-length mt-ApsRS coding sequence (either wild type or containing 
the mutation corresponding to S45G) cloned into pEGFP-N1 (Clontech). The mt-AspRS amplicon was amplified from pQE70-mt-AspRS [11]. Constructs used in the in vitro import and processing assays, PCR-generated truncated mt-AspRS versions (from aa 1 to 313, with or without the mutation) were cloned into $\mathrm{pCR}^{\circledR} 2.1$ vector (Invitrogen) downstream of a T7 promoter. A Kozak consensus sequence (5'-GCCATG-3') was introduced during the PCR for the translation of the corresponding proteins. The plasmid expressing the 81 first aa of $A$. thaliana mtGluRS upstream the GFP sequence was published before [17].

\section{Cell culture and visualization of the mt-AspRS-GFP fusion protein variants}

HEK 293T cells were maintained in Dulbecco's modified Eagle's medium (DMEM, Invitrogen) supplemented with $10 \%$ fetal bovine serum, $100 \mathrm{U} / \mathrm{ml}$ penicillin and $100 \mu \mathrm{g} / \mathrm{ml}$ streptomycin at $37{ }^{\circ} \mathrm{C}$, in a $10 \% \mathrm{CO}_{2}$ humidified incubator. Cells were seeded onto coverslips at $3 \times 10^{5}$ cells per $35 \mathrm{~mm}$ dish. At semi-confluence, cells were transiently transfected by the calcium phosphate method with 500 ng of plasmids. After $36 \mathrm{~h}$, Mitotracker Red CM- $\mathrm{H}_{2} \mathrm{XRos}$ (Invitrogen) was added to a final concentration of $100 \mathrm{nM}$ for $30 \mathrm{~min}$. Images were obtained using confocal microscopy as described [17].

\section{Human mitochondria purification}

Mitochondria were purified from HEK 293T cell lysates (warring blender) by differential centrifugations at $1,500 \mathrm{~g}$ followed by final step at $20,500 \mathrm{~g}$ for $25 \mathrm{~min}$ in $5 \mathrm{mM}$ HEPES$\mathrm{KOH} \mathrm{pH} 7.5,210 \mathrm{mM}$ mannitol, $70 \mathrm{mM}$ sucrose, $2 \mathrm{mM}$ EDTA, 0.5\% BSA, $2 \mathrm{mM} \beta-$ mercaptoethanol. The pellet of mitochondria was washed twice either in the import buffer (10 $\mathrm{mM}$ HEPES-KOH $\mathrm{pH} 7.5,25 \mathrm{mM}$ sucrose, $75 \mathrm{mM}$ sorbitol, $100 \mathrm{mM} \mathrm{KCl}, 10 \mathrm{mM}$ $\mathrm{KH}_{2} \mathrm{PO}_{4} / \mathrm{K}_{2} \mathrm{HPO}_{4} \mathrm{pH} 7.5,0.05 \mathrm{mM}$ EDTA, $5 \mathrm{mM} \mathrm{MgCl}_{2}$ ) or in the import buffer without EDTA for the processing assay and kept on ice. Concentration of $\mathrm{mt}$ proteins was measured by a Bradford assay.

\section{In vitro assays}

In vitro synthesis of proteins in the presence of $\left[{ }^{35} \mathrm{~S}\right]$-methionine $(1000 \mathrm{Ci} / \mathrm{mmol}$, Amersham $)$ was carried out with the TNT ${ }^{\circledR}$ T7 Coupled Reticulocyte Lysate System (Promega) following the manufactor's procedures. Import assays were performed as previously described [17]. The incubation time (30 min) is sufficient to cover the full process of import and maturation [18]. In vitro processing assays were performed as previously described [19]. Briefly, sonicated HEK $293 \mathrm{~T}$ mitochondria (3 rounds of sonication for $10 \mathrm{sec}$, medium speed, bioruptor, Diagenode) were diluted 2-fold in a processing buffer containing $40 \mathrm{mM}$ HEPES pH 7.3, 2 $\mathrm{mM} \mathrm{MnCl}, 2,2 \%$ Tween, $2 \mathrm{mM}$ DTT and $1 \mathrm{X}$ protease inhibitor cocktail EDTA free. Five $\mu 1$ of $\left[{ }^{35} \mathrm{~S}\right]$-labeled fusion proteins were then added to $30 \mu \mathrm{lof} \mathrm{mt}$ suspension. After $3 \mathrm{~h}$ incubation at $30{ }^{\circ} \mathrm{C}$ samples were analyzed by SDS-PAGE and autoradiography.

\section{RESULTS \& DISCUSSION}

\section{Mutated mt-AspRS co-localizes with mitochondria}

To determine the possible consequences of the mutation on any of the mt protein import steps, targeting to mitochondria was first explored. HEK 293T cells, transfected with GFP fusion protein constructs, were visualized by confocal microscopy. While mt-AspRS lacking its theoretical MTS (residues 1-48) is exclusively present within the cytosol, both mt-AspRS and (S45G)mt-AspRS possessing their MTS co-localize with mitochondria (Fig. 2). Noteworthy, GFP fused to the mt-AspRS MTS alone also co-localizes with the mt specificmarker, showing that the $48 \mathrm{~N}$-terminal amino acids (aa) of mt-AspRS are sufficient to guide 
this protein to mitochondria in vivo. In addition, S45G neither impaired targeting nor binding of mt-AspRS to mitochondria. Next, import through the mt membranes was analyzed.

\section{Mutated MTS prevents import of mt-AspRS into mitochondria}

The impact of the mutation on the import process was tested by in vitro import assays of $\left[\mathrm{S}^{35}\right]$-radiolabeled proteins into mitochondria purified from HEK 293T cells. MtGluRS-GFP (first $81 \mathrm{~N}$-term aa of Arabidopsis thaliana GluRS fused to GFP) was used as a positive control. This protein was previously successfully used for assays studying import and processing into isolated plant mitochondria under well-defined experimental conditions [17]. Figure $3 \mathrm{~A}$ shows that this protein is also imported and processed into purified human mitochondria.

Comparable to the $A$. thaliana mtGluRS variant, a truncated version of mt-AspRS was used (N-terminal 313 aa including MTS) for good resolution of precursor and processed proteins on SDS-PAGE. Processed forms of mt-AspRS, resistant to proteinase $\mathrm{K}$, were observed, confirming proper import into mitochondria of this protein (Fig. 3B). The size difference of $\sim 6 \mathrm{kDa}$ between the precursor and processed products is in agreement with the expected removal of the theoretical MTS. Import was restrained as expected in the presence of valinomycin, an uncoupling agent inhibiting protein import [17]. Two observations were made for (S45G)mt-AspRS. First, the mutated precursor protein bound to mitochondria as efficiently as the wild-type form since both proteins were recovered with mitochondria after a sucrose cushion purification step (Fig. 3B and 3C, lane 2). This binding is consistent with the confocal microscopy experiments (Fig. 2). Second, in contrast to mt-AspRS, no processed versions of the protein were visible (Fig. 3C, lanes 2 and 3). This absence of mature product strongly suggests that mutation $\mathrm{S} 45 \mathrm{G}$ affects the import process, either at the translocation step through the double mt-membrane, or at the MTS-processing step. Actually, it has been shown that a non-processed protein is thermally less stable in mt matrix and more rapidly degraded than a mature protein [20]. Therefore, effect of mutation on those two steps has been further investigated. In addition, incomplete degradation of mt-AspRS or (S45G)mt-AspRS by proteinase $\mathrm{K}$ (Fig. 3B and 3C, lane 3) suggests that in vitro import of these human proteins is slower or less efficient than the mtGluRS-GFP fusion protein (Fig. 3A, lane 3).

\section{Mutated AspRS precursor can be cleaved off by mitochondrial peptidases but is not translocated through the mitochondrial membranes}

To discriminate between the two above-mentioned steps, an in vitro processing experiment was performed. The same radiolabeled proteins (mtGluRS-GFP, mt-AspRS, (S45G)mt-AspRS) were incubated with a mt enzymatic extract from HEK 293T cells containing active $\mathrm{mt}$ processing peptidases [19]. No processing products were visible in the absence of the mt enzymatic extract for any of the three proteins (Fig. 4). Incubation with the $\mathrm{mt}$ extract led to the expected processed products, with identical differences in size between precursor and processed forms than the ones obtained in the in vitro import assay. Interestingly, the processing assay shows that the pathogenic mutation S45G did not prevent removal of MTS by mt peptidases. Therefore, if the mutated (S45G)mt-AspRS would be present inside the mitochondria, its MTS could be processed by $\mathrm{mt}$ peptidases. Combining these results indicates that the absence of a processed form of (S45G)mt-AspRS (Fig. 3C) appears to be due to non-translocation of the protein and not to some inherent defect in its ability to be processed.

\section{Mitochondrial import failure of an aminoacyl-tRNA synthetase in LBSL}

Many mutations in DARS2 have been associated with LBSL. Here, we have analyzed the sole mutation known to be located in the MTS and nearby the predicted processing site 
(Fig. 1). Interestingly, while the import machineries are well conserved between species of a same kingdom, each mt protein has its own MTS. Consequently, rules about the nature and the position of crucial residues for mt import cannot be precisely defined. The identity of those aa is likely to be studied on a case-by-case protein basis and molecular consequences of mutations within MTS cannot be anticipated. For instance, in A. thaliana, Ala to Ser mutation at MTS position 2 of mt-GluRS and mt-MetRS or Thr to Gly change of mt-PheRS respectively enhances, inhibits or doesn't affect their mt import [21]. Thus, the consequence of mutation S45G on the import process of mt-AspRS could not be foreseen before this study. However, the strong conservation of Ser45 within MTS of mammalian mt-AspRSs (Fig. 1) suggested a role in their import. Here we show that S45G has a clear impact on the import process. Confocal microscopy imaging reveals that it does not affect the targeting, or the binding to mitochondria. In vitro import and processing assays designate the import, and more precisely the translocation step, to be impaired by the mutation. This is a novel point of impact for a pathology-related mutation regarding a translation machinery protein. Strikingly, S45G has been described to not have any consequence on mt activity [4]. This remains puzzling but an answer may arise from the fact that patients are compound-heterozygous for this mutation, the other mutation leading to only a weak expression of wild-type protein. This low level is apparently sufficient to support $\mathrm{mt}$ translation in the cells that were tested. Whether this is different in brain white matter cells has not been studied. It could also be that the mutation affects another, but still unknown, function of the protein [22]. Remarkably and for unknown reasons this compound-heterozygosity phenomenon is common to all the DARS2 mutations reported so far [5].

\section{Mitochondrial import failure and diseases}

Two major types of $\mathrm{mt}$ import defects have been reported to be associated with disorders (for a review, see [23]). Either the components of the mt import and/or processing machinery are directly affected or mutations are present in the MTS, reducing the mt import of the corresponding protein. The Deafness Dystonia Syndrome as well as a form of cardiomyopathy are for example caused by mutations in the genes encoding small proteins of the inner mt membrane [24, 25]. Only two cases were reported so far with mutations affecting the MTS: a pyruvate dehydrogenase deficiency leading to abnormalities in the central nervous system [26], and partial arrest of manganese superoxide dismutase precursor protein within the inner mt membrane likely modulating susceptibility to various diseases [27]. For LBSL we describe a novel finding: the impairment of the import of a crucial translation machinery protein is correlated with a white matter disorder. It can be anticipated that new diseaserelated mutations will be found in MTS of proteins involved in any aspect of mitochondrial biogenesis.

\section{ACKNOWLEDGMENTS}

J. Mutterer (Microscopy and Imaging Platform, IBMP, Strasbourg) is acknowledged for help in confocal microscopy imaging. We are grateful to J.C. Paillart, N. Entelis, I. Tarassov, N. Saad and F. Sieber for advices and gifts of material.

\section{FUNDING}

This work was supported by Association Française contre les Myopathies (AFM), Centre National de la Recherche Scientifique (CNRS) and Université de Strasbourg. M.M. was supported by a fellowship from Ministère de l'Enseignement Supérieur et de la Recherche and by l'Agence Nationale de la Recherche (ANR) and H.S. by a fellowship from Région Alsace. 


\section{REFERENCES}

1 Tuppen, H. A., Blakely, E. L., Turnbull, D. M. and Taylor, R. W. (2010) Mitochondrial DNA mutations and human disease. Biochim. Biophys. Acta. 1797, 113-128

2 Wallace, D. C. (2010) Mitochondrial DNA mutations in disease and aging. Environ. Mol. Mutagen. 51, 440-450

3 Jacobs, H. T. and Turnbull, D. M. (2005) Nuclear genes and mitochondrial translation: a new class of genetic disease. Trends Genet. 21, 312-314

4 Scheper, G. C., van der Klok, T., van Andel, R. J., van Berkel, C. G., Sissler, M., Smet, J., Muravina, T. I., Serkov, S. V., Uziel, G., Bugiani, M., Schiffmann, R., KragelohMann, I., Smeitink, J. A., Florentz, C., Coster, R. V., Pronk, J. C. and van der Knaap, M. S. (2007) Mitochondrial aspartyl-tRNA synthetase deficiency causes leukoencephalopathy with brain stem and spinal cord involvement and lactate elevation. Nat. Genet. 39, 534-539

5 Lin, J., Faria, E. C., Da Rocha, A. J., Masruha, M. R., Vilanova, L. C., Scheper, G. C. and Van der Knaap, M. S. (2010) Leukoencephalopathy With Brainstem and Spinal Cord Involvement and Normal Lactate: A New Mutation in the DARS2 Gene. J. Child. Neurol. 25, 1425-1428

6 Isohanni, P., Linnankivi, T., Buzkova, J., Lönnqvist, T., Pihko, H., Valanne, L., Tienari, P. J., Elovaara, I., Pirttilä, T., Reunanen, M., Koivisto, K., Marjavaara, S. and Suomalainen, A. (2010) DARS2 mutations in mitochondrial leucoencephalopathy and multiple sclerosis. J. Med. Genet. 47, 66-70

7 Edvardson, S., Shaag, A., Kolesnikova, O., Gomori, J. M., Tarassov, I., Einbinder, T., Saada, A. and Elpeleg, O. (2007) Deleterious mutation in the mitochondrial arginyltransfer RNA synthetase gene is associated with pontocerebellar hypoplasia. Am. J. Hum. Genet. 81, 857-862

8 Riley, L. G., Cooper, S., Hickey, P., Rudinger-Thirion, J., McKenzie, M., Compton, A., Lim, S. C., Thorburn, D., Ryan, M. T., Giegé, R., Bahlo, M. and Christodoulou, J. (2010) Mutation of the mitochondrial tyrosyl-tRNA synthetase gene, YARS2, causes myopathy, lactic acidosis, and sideroblastic anemia--MLASA syndrome. Am. J. Hum. Genet. 87, 5259

9 Antonellis, A., Ellsworth, R. E., Sambuughin, N., Puls, I., Abel, A., Lee-Lin, S. Q., Jordanova, A., Kremensky, I., Christodoulou, K., Middleton, L. T., Sivakumar, K., Ionasescu, V., Funalot, B., Vance, J. M., Goldfarb, L. G., Fischbeck, K. H. and Green, E. D. (2003) Glycyl tRNA synthetase mutations in Charcot-Marie-Tooth disease type 2D and distal spinal muscular atrophy type V. Am. J. Hum. Genet. 72, 1293-1299

10 Xie, W., Nangle, L. A., Zhang, W., Schimmel, P. and Yang, X. L. (2007) Long-range structural effects of a Charcot-Marie-Tooth disease-causing mutation in human glycyltRNA synthetase. Proc. Natl. Acad. Sci. U.S.A. 104, 9976-9981

11 Bonnefond, L., Fender, A., Rudinger-Thirion, J., Giegé, R., Florentz, C. and Sissler, M. (2005) Towards the full set of human mitochondrial aminoacyl-tRNA synthetases: characterization of AspRS and TyrRS. Biochemistry. 44, 4805-4816

12 Gakh, O., Cavadini, P. and Isaya, G. (2002) Mitochondrial processing peptidases. Biochim. Biophys. Acta. 1592, 63-77

13 Neupert, W. and Herrmann, J. M. (2007) Translocation of proteins into mitochondria. Annu. Rev. Biochem. 76, 723-749

14 Baker, M. J., Frazier, A. E., Gulbis, J. M. and Ryan, M. T. (2007) Mitochondrial proteinimport machinery: correlating structure with function. Trends Cell Biol. 17, 456-464

15 Bolender, N., Sickmann, A., Wagner, R., Meisinger, C. and Pfanner, N. (2008) Multiple pathways for sorting mitochondrial precursor proteins. EMBO Rep. 9, 42-49 
16 van der Laan, M., Hutu, D. P. and Rehling, P. (2010) On the mechanism of preprotein import by the mitochondrial presequence translocase. Biochim. Biophys. Acta. 1803, $732-739$

17 Duchêne, A. M., Giritch, A., Hoffmann, B., Cognat, V., Lancelin, D., Peeters, N. M., Zaepfel, M., Maréchal-Drouard, L. and Small, I. D. (2005) Dual targeting is the rule for organellar aminoacyl-tRNA synthetases in Arabidopsis thaliana. Proc. Natl. Acad. Sci. U.S.A. 102, 16484-16489

18 Hammen, P. K., Waltner, M., Hahnemann, B., Heard, T. S. and Weiner, H. (1996) The role of positive charges and structural segments in the presequence of rat liver aldehyde dehydrogenase in import into mitochondria. J. Biol. Chem. 271, 21041-21048

19 Ou, W. J., Ito, A., Okazaki, H. and Omura, T. (1989) Purification and characterization of a processing protease from rat liver mitochondria. EMBO J. 8, 2605-2612

20 Mukhopadhyay, A., Yang, C. S., Wei, B. and Weiner, H. (2007) Precursor protein is readily degraded in mitochondrial matrix space if the leader is not processed by mitochondrial processing peptidase. J. Biol. Chem. 282, 37266-37275

21 Pujol, C., Maréchal-Drouard, L. and Duchêne, A. M. (2007) How can organellar protein $\mathrm{N}$-terminal sequences be dual targeting signals? In silico analysis and mutagenesis approach. J. Mol. Biol. 369, 356-367

22 Guo, M., Yang, X. L. and Schimmel, P. (2010) New functions of aminoacyl-tRNA synthetases beyond translation. Nat. Rev. Mol. Cell. Biol. 11, 668-674

23 MacKenzie, J. A. and Payne, R. M. (2007) Mitochondrial protein import and human health and disease. Biochim. Biophys. Acta. 1772, 509-523

24 Koehler, C. M., Leuenberger, D., Merchant, S., Renold, A., Junne, T. and Schatz, G. (1999) Human deafness dystonia syndrome is a mitochondrial disease. Proc. Natl. Acad. Sci. U.S.A. 96, 2141-2146

25 Davey, K. M., Parboosingh, J. S., Mcleod, D. R., Chan, A., Casey, R., Ferreira, P., Snyder, F. F., Bridge, P. J. and Bernier, F. P. (2006) Mutation of DNAJC19, a human homologue of yeast inner mitochondrial membrane co-chaperones, causes DCMA syndrome, a novel autosomal recessive Barth syndrome-like condition. J. Med. Genet. 43, 385-393

26 Takakubo, F., Cartwright, P., Hoogenraad, N., Thorburn, D. R., Collins, F., Lithgow, T. and Dahl, H. H. (1995) An amino acid substitution in the pyruvate dehydrogenase E1 alpha gene, affecting mitochondrial import of the precursor protein. Am. J. Hum. Genet. 57, 772-780

27 Sutton, A., Khoury, H., Prip-Buus, C., Cepanec, C., Pessayre, D. and Degoul, F. (2003) The Ala16Val genetic dimorphism modulates the import of human manganese superoxide dismutase into rat liver mitochondria. Pharmacogenetics. 13, 145-157 


\section{FIGURE LEGENDS}

Figure 1. Multiple sequence alignment of the N-terminal region of human mt-AspRS with a selection of known AspRSs. Accession numbers of sequences are $\mathrm{mt} H$. sapiens, NP_060592.2; mt C. jacchus, XP_002760400; $\mathrm{mt}$ B. taurus, NP_001095692; mt E. caballus, XP_001493136; mt M. musculus, NP_766232; mt A. thaliana, NP_195102; mt $S$. cerevisiae, $\mathrm{NP}$-015221; E. coli, NP_416380; B. subtilis, NP_390633; S. aureus, NP 372154. Black and gray boxes highlight identical and similar residues, respectively. Predicted cleavage position of mt-AspRS mitochondrial targeting sequence is indicated by a gray arrowhead. The $S$ residue mutated into $G$ at position 45 in the human mt-AspRS is pinpointed by a black arrowhead.

Figure 2. Subcellular localization of GFP-fused mt-AspRS derivatives in human HEK 293T cells. Schematic representations of the 4 GFP-fused protein constructs are indicated. Cells were transiently transfected with full-length (1-645 aa) or partial (1-48 or 48-645 aa) sequences of mt-AspRS and fluorescence signals visualized by confocal microscopy. S45G mutation is highlighted with an arrowhead. Column A: GFP fluorescence; column B: mt marker (Mitotracker Red CM-H 2 XRos); column C: merge. Integrity of nuclei of HEK 293T cells following transient expression of MTS-mt-AspRS-GFP or MTS(S45G)-mt-AspRS-GFP was verified by staining with 4',6-diamidino-2-phenylindole (DAPI) (not shown).

Figure 3. In vitro import experiments with purified human mitochondria. Experiments were performed with three constructs: A. As a control, mtGluRS-GFP (81 first aa of $A$. thaliana mtGluRS upstream the GFP sequence) [17], B. Human mt-AspRS 313 first amino acids and C. (S45G)mt-AspRS. Radioactive full-length precursors obtained by in vitro transcription/translation (lane 1), were incubated with mitochondria purified from human HEK 293T cells (lanes 2 to 5) for $30 \mathrm{~min}$, and further purified on sucrose gradient before separation on SDS-PAGE and autoradiography. Proteinase K degrades proteins present at the $\mathrm{mt}$ surface but does not affect proteins located inside mitochondria. Preincubation with valinomycin inhibits protein import. Molecular weights were calculated based upon marker proteins. Each assay was independently performed at least three times, with no significant variations.

Figure 4. Processing of precursor proteins by a human mitochondrial peptidase extract. The experiment was performed with the same constructs used in Figure 3. Radioactive fulllength precursor proteins of mtGluRS-GFP, MTS-mt-AspRS and (S45G)MTS-mt-AspRS obtained by in vitro transcription/translation were incubated in the absence (-) or in the presence $(+)$ of a HEK $293 \mathrm{~T} \mathrm{mt} \mathrm{enzymatic} \mathrm{extract.} \mathrm{Three} \mathrm{independent} \mathrm{sets} \mathrm{of} \mathrm{experiments}$ were performed and showed identical patterns. Precursor and processed forms are indicated. Molecular weights have been calculated according to marker proteins. ${ }^{*}=$ non specific products synthesized with the TNT® T7 Coupled Reticulocyte Lysate System. 


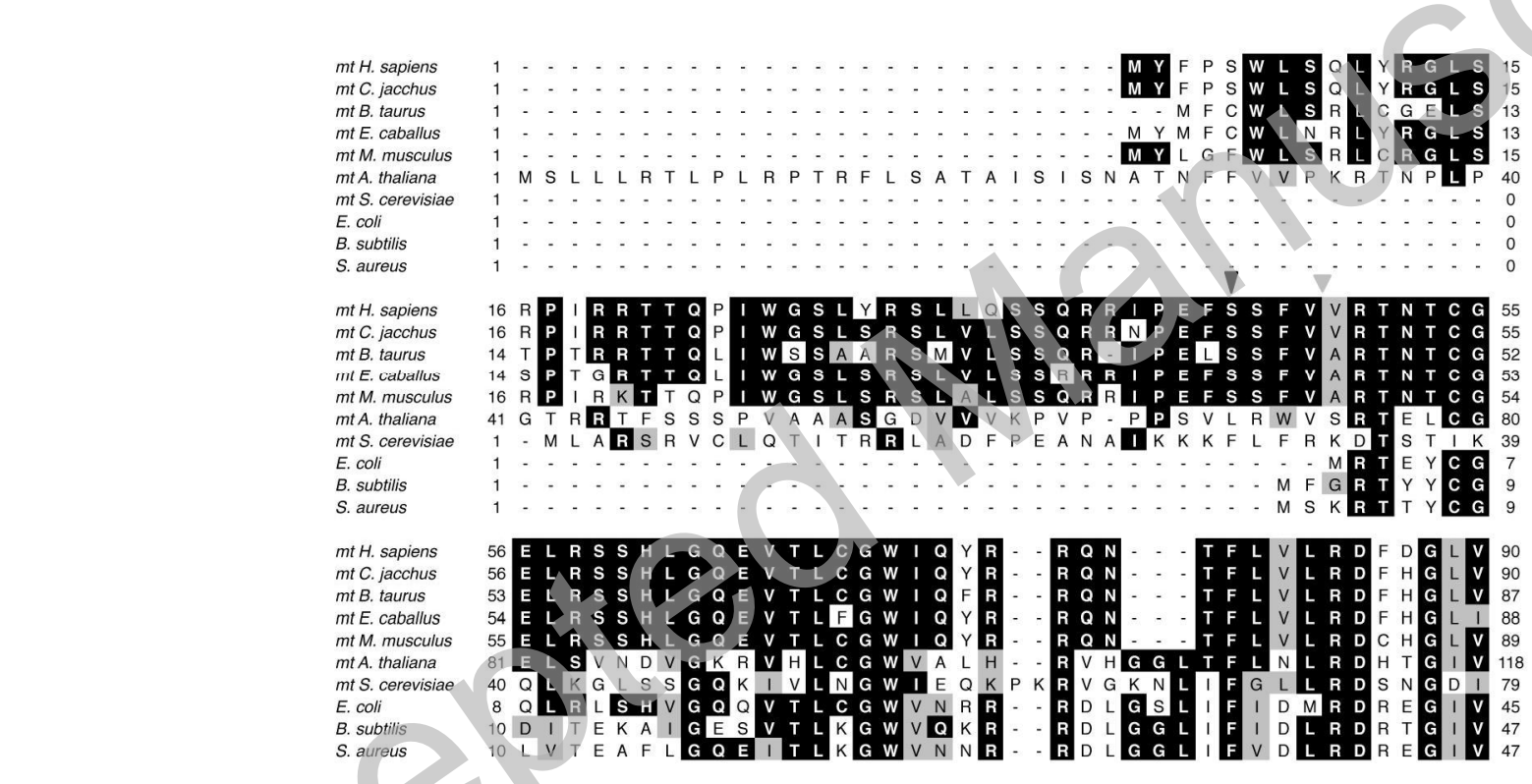




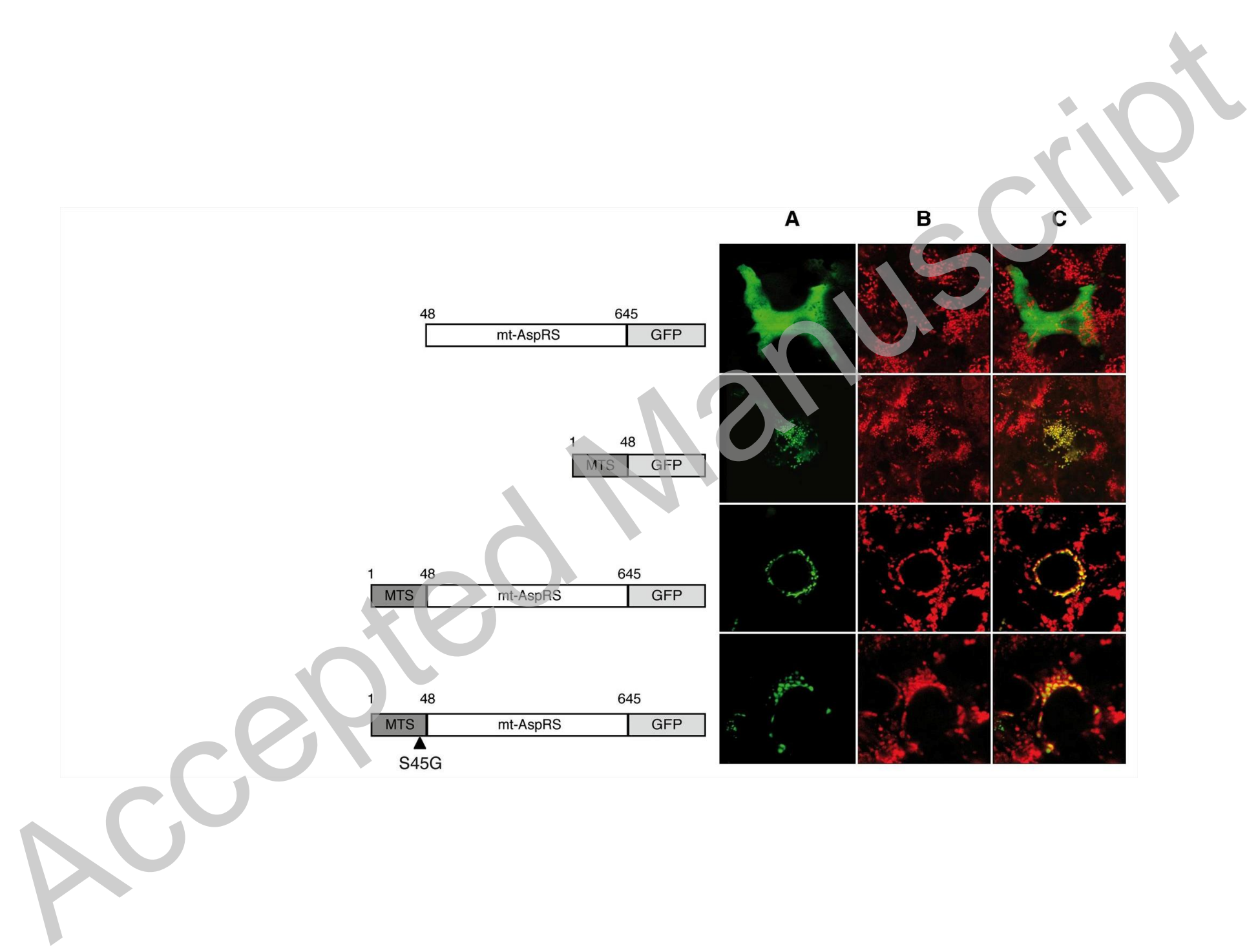



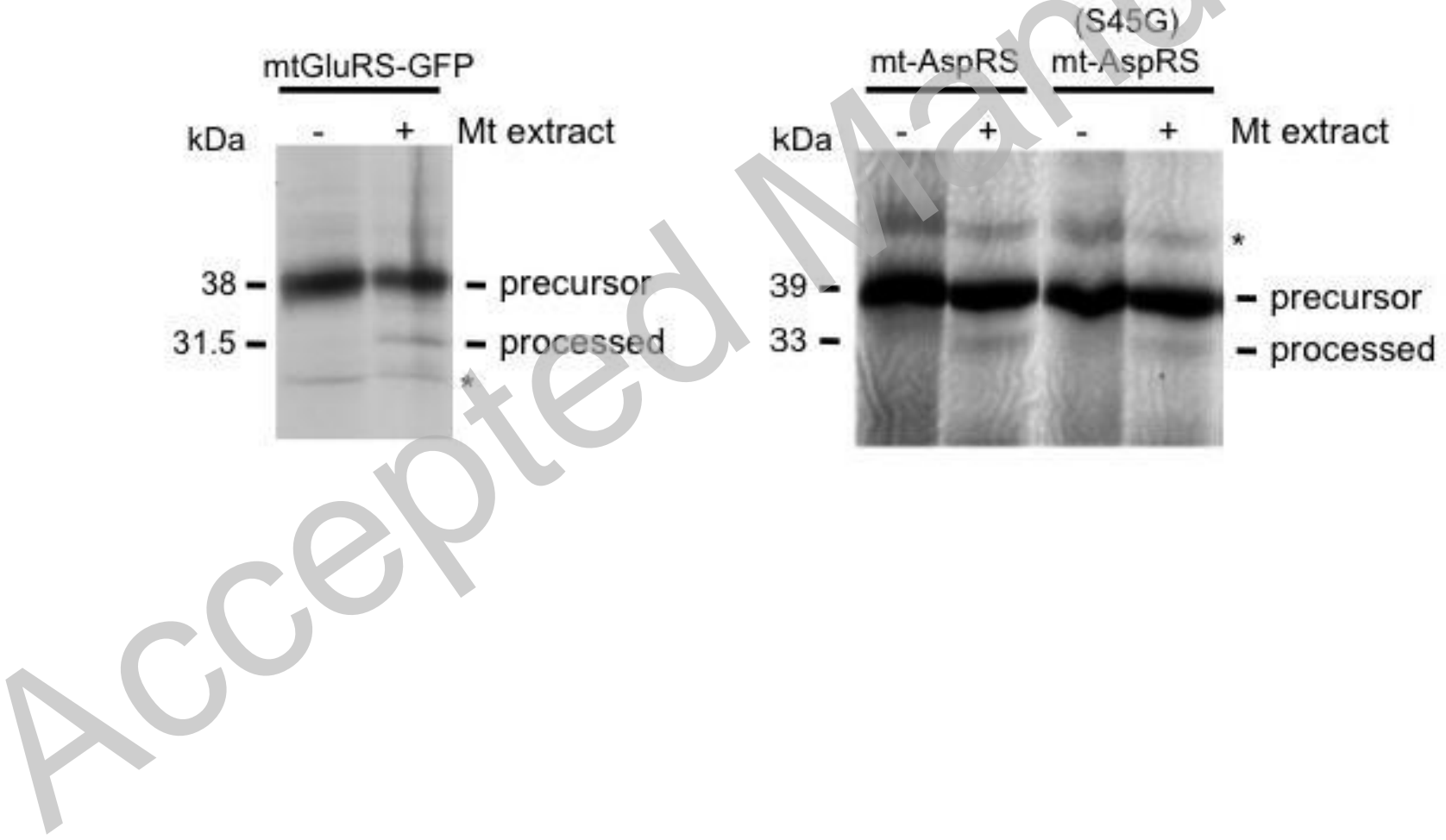